\title{
Hydrogen Materials Compatibility FY 2007 Final Report
}

\author{
J Holberry \\ $\mathrm{CH}$ Henager, Jr. \\ S Pitman \\ J Ryan
}

October 2007

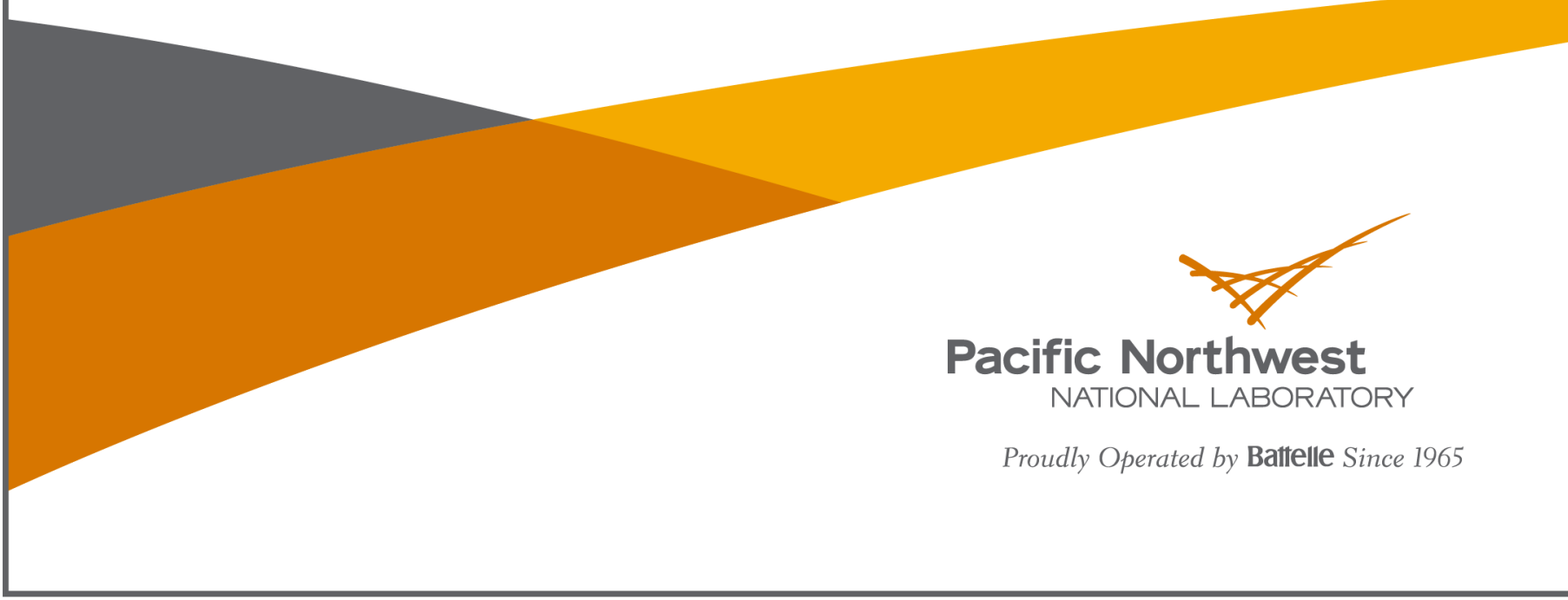




\title{
DISCLAIMER
}

This report was prepared as an account of work sponsored by an agency of the United States Government. Neither the United States Government nor any agency thereof, nor Battelle Memorial Institute, nor any of their employees, makes any warranty, express or implied, or assumes any legal liability or responsibility for the accuracy, completeness, or usefulness of any information, apparatus, product, or process disclosed, or represents that its use would not inf ringe privately owned rights. Reference herein to any specific commercial product, process, or service by trade name, trademark, manufacturer, or otherwise does not necessarily constitute or imply its endorsement, recommendation, or favoring by the United States Government or any agency thereof, or Battelle Memorial Institute. The views and opinions of authors expressed herein do not necessarily state or reflect those of the United States Government or any agency thereof.

\author{
PACIFIC NORTHWEST NATIONAL LABORATORY \\ operated by \\ BATTELLE \\ for the \\ UNITED STATES DEPARTMENT OF ENERGY \\ under Contract DE-AC05-76RL01830
}

Printed in the United States of America
Available to DOE and DOE contractors from the
Office of Scientific and Technical Information,
P.O. Box 62, Oak Ridge, TN 37831-0062;
ph: (865) 576-8401
fax: $(865) 576-5728$
email: reports $(\boldsymbol{a})$ donis.osti.gov

Available to the public from the National Technical Information Service

5301 Shawnee Rd., Alexandria, VA 22312

ph: (800) 553-NTIS (6847)

email: orders@ntis.gov $<$ http://www.ntis.gov/about/form.aspx $>$

Online ordering: http://www.ntis.gov

This document was printed on recycled paper. 


\section{Hydrogen Materials Compatibility}

Chuck Henager, Jr., Stan Pitman, Joe Ryan, James Holbery

Pacific Northwest National Laboratory

P.O. Box 999

Richland, Washington 99354

(509) 375-3686; fax: (509) 375-2379; e-mail: james.holbery@pnl.gov

Peter Blau, Jun Qu

Oak Ridge National Laboratory

Oak Ridge, TN 37831

(865)574-5377; fax: (865) 574-6981; e-mail: blaupj@ornl.gov

DOE Technology Development Manager: Jerry Gibbs

(202) 586-1182; fax: (202) 586-1600; e-mail: jerry.gibbs@ee.doe.gov

Contractor: Pacific Northwest National Laboratory, Richland, Washington

Prime Contract No.: DE AC06 76RLO 1830

\section{Objectives}

- Measure the friction and wear characteristics of injector materials in hydrogen environments, including in-situ and ex-situ materials characterization.

- Measure the performance of piezoelectric actuators and actuator materials in hydrogen environments.

- Develop a design approach to hydrogen injectors based on material behavior and performance in hydrogen based on experimental data.

\section{Approach}

- Develop quantifiable performance test data on piezo materials in high-pressure $100 \%$ hydrogen.

- Conduct failure analysis of actuator piezo materials and epoxy layers.

- Develop diffusion models to predict hydrogen diffusion effect on metallic, polymer, and piezo materials.

- Develop sliding wear quantified data on injector materials, coatings in hydrogen environment.

- Conducted hydrogen diffusion modeling, exposure testing, and failure analysis on injector piezo materials.

- Conducted hydrogen exposure and friction-wear testing of candidate injector needle-nozzle pairs.

- Completed the design, construction, safety check, and full operation of a high-pressure hydrogen insitu friction and wear test apparatus.

- Conducted characterization of the piezo polymer coatings.

Future Direction

- Understand and predict the fundamental material degradation / performance / aging mechanisms of injector materials in a hydrogen service environment.

- Develop accelerated test methods and durability procedures for materials/coatings used on hydrogen injectors.

- Develop a series of coatings at PNNL and with suppliers including Argonne National Laboratory, characterize their application to injector needle-nozzle design, and quantify their performance for HICE application. Coatings include nano-structured coatings produced at PNNL, diamond-like-carbon coatings produced at ANL and obtained by industry suppliers. 


\section{Injector Needle-Nozzle Analysis - Test}

The injector needle nozzle is viewed as a critical component in the direct-inject hydrogen internal combustion engine. If the pair does not operate properly, a loss of power and fuel efficiency is experienced. To address this problem, the program team has approached the problem with the following methodology:

A. To develop a predictive engineering tool to model the contact stress of the needle-nozzle interface under different sliding-impact conditions to aid in material and coating selection. This tool is capable of accommodating a variety of coating and substrate materials and will be of significant value as we develop a series of new designs in FY08.

B. To conduct extensive ex-situ experiments on candidate materials that have been previously exposed to a hydrogen environment.

C. To design, build, and employ an in-situ sliding friction test apparatus to develop material properties in hydrogen service conditions.

The finite element model was developed to predict the effect of a coating on the contact stresses within a hydrogen fuel injector needle/nozzle set. The figures that follow depict case studies of different material combinations at different conditions with the resulting maximum reported.

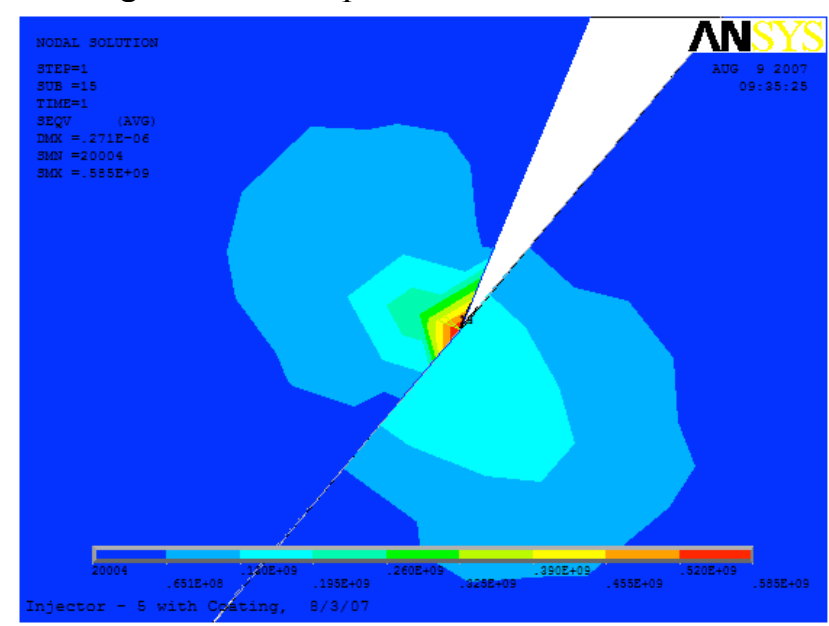

Figure 1: Elastic, coating modulus set to $400 \mathrm{MPa}$ with a corresponding max. stress $=585 \mathrm{MPa}$

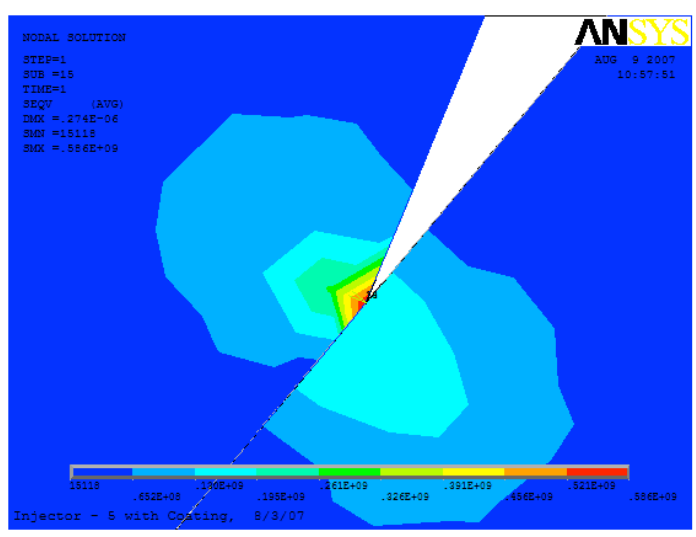

Figure 2: Elastic, coating and pin moduli set equal at $210 \mathrm{GPa}$. The mesh has been refined and the maximum stress $=586 \mathrm{MPa}$

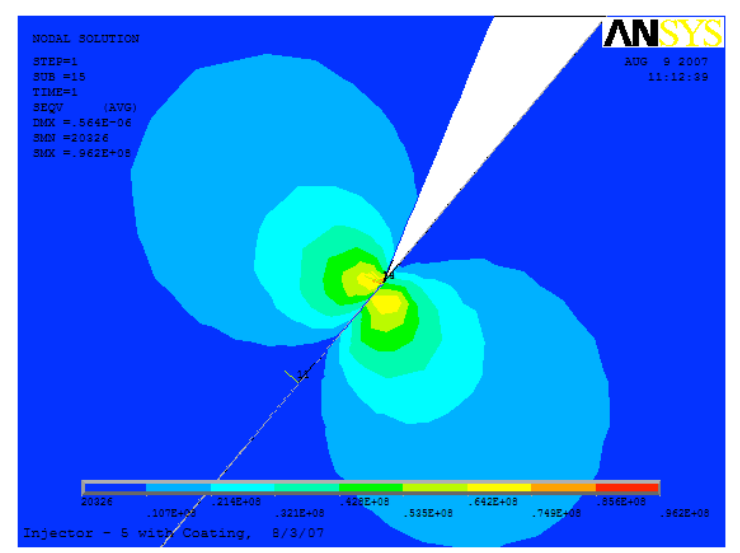

Figure 3: The elastic plastic distribution is defined by a yield stress, coating moduli is set to $300 \mathrm{GPa}$. Maximum stress $=96.2 \mathrm{Mpa}$

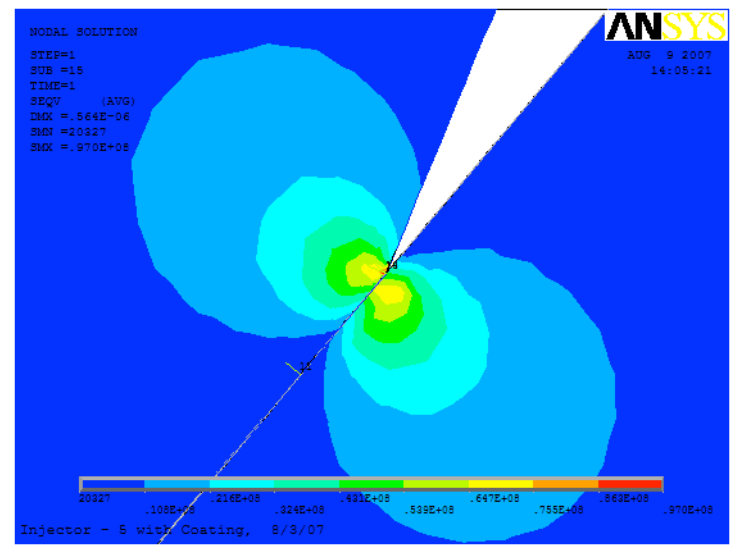

Figure 4: Elastic plastic distribution, coating moduli set to $400 \mathrm{GPa}$, yield stress were updated $3 \mathrm{GPa}$ for the pin, $1.7 \mathrm{GPa}$ for the seat and $3 \mathrm{GPa}$ for the coating. Maximum stress $=97 \mathrm{Mpa}$ 
For the trials conducted, it has been determined that the coating does not have a significant effect on the maximum stress obtained by the impact force, although the distribution of that stress does change slightly. It likely has more of an effect on surface sliding; surface loads have not yet been modeled in this study. The coating has a much higher modulus of elasticity then the pin; therefore, it should be able to experience much higher stresses. A fatigue model may give more insight into the actual numbers these coatings may tolerate. Examples of output plotted from our study follow; maximum stress versus coating moduli with set substrate moduli (representing the needle base materials); friction versus maximum stress as a fun of coating moduli; and von Mises plastic strain as a function of cycle number for a substrate with a yield stress $=200 \mathrm{MPa}$. When employed for our coating study in FY08, these predictive finite element tools will be instrumental in predicting needle-nozzle-coating material combination.

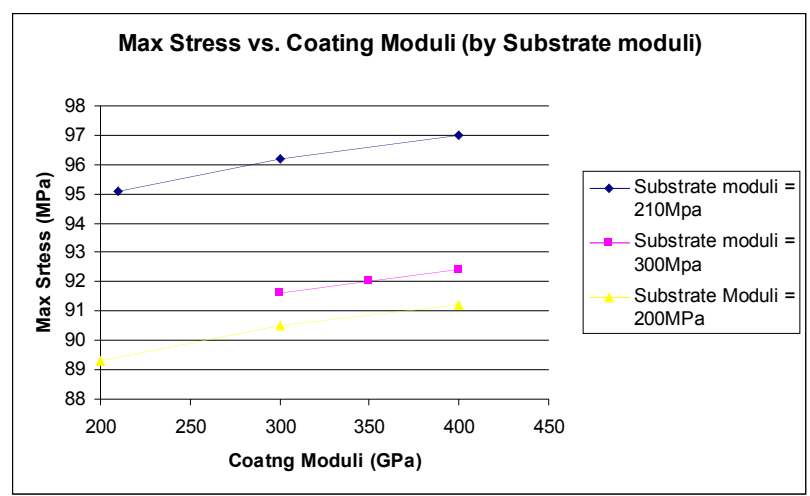

Figure 5: Maximum stress versus coating moduli as a function of substrate modulus.

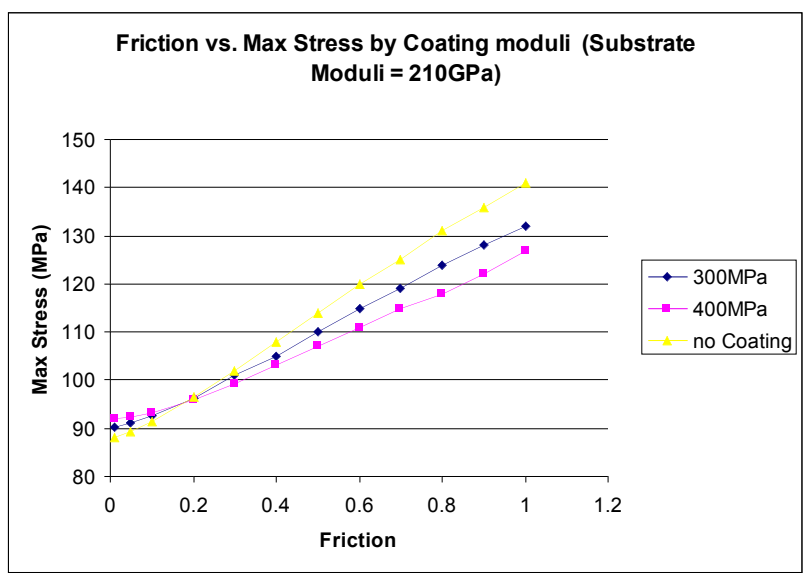

Figure 6: Friction coefficient versus maximum stress as a function of coating property.

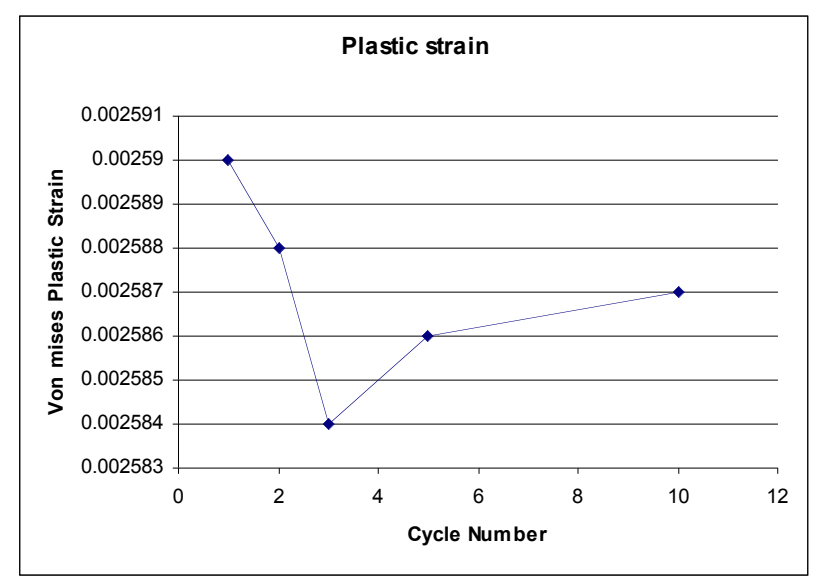

Figure 7: von Mises plastic strain versus number of cycles of a $200 \mathrm{MPa}$ substrate.

\section{Ex-Situ Friction-Wear of Needle-Nozzle Materi- als (with ORNL)}

The effects of hydrogen exposure on tribological characteristics have been investigated for hydrogen internal combustion engine needle-nozzle materials. Scuffing-resistance, identified as the critical tribological properties for the needle-nozzle component, was evaluated for candidate needle-nozzle materials with different hydrogen exposure levels. Tests were conducted under pin-on-flat reciprocating sliding in an inert (argon) environment to eliminate the oxidation effects.

The critical tribological issue for needle-nozzle component in hydrogen-fuel engines is scuffing, which may cause the needle to stick or seize. The term 'scuffing' has been used to describe surface damage in various contexts throughout the field of engineering. For the purposes this study, the following definition for scuffing has been adopted: a form of sliding-induced contact damage to a bearing surface, usually associated with asperity-scale plastic deformation, that results in localized and perceptible changes in roughness or appearance without significantly altering the geometric form of the part on which the damage occurs.

The onset of scuffing has been determined in these tests because the onset of scuffing can quickly lead to catastrophic failure due to the tight geometric tolerance between the needle and nozzle. In this study the effect of hydrogen exposure on materials' tribological characteristics are ranked by the scuffingresistance of candidate needle-nozzle materials. 
The materials tested are provided in Table 1, and the test matrix in Table 1. Friction and wear characteristics of materials with different exposure lengths in hydrogen were investigated. Tests were conducted using a pin-on-flat reciprocating sliding configura- tion (Figure 8) under $1 \mathrm{~N}$ normal load, at 5 or 4.17 $\mathrm{Hz}$ oscillation frequencies with $4.3 \mathrm{~mm}$ stroke, and in both ambient (air) and inert (Argon) environments. Test duration varied from 6250 to 108000 cycles.

\begin{tabular}{|c|c|c|c|c|c|c|}
\hline Material & Manufacturer & Composition & $\begin{array}{l}\text { Certified } \\
\text { (Yes/No) }\end{array}$ & $\begin{array}{l}\text { Heat Treat. } \\
\text { - Case Hard. }\end{array}$ & Coating & Hv (Avg.) \\
\hline H13 Steel & $\begin{array}{l}\text { Metal Samples } \\
\text { Co., AL, USA }\end{array}$ & $\begin{array}{l}5 \% \mathrm{Cr} 1.3 \% \mathrm{Mo} \\
1.1 \% \mathrm{~V}\end{array}$ & Yes & $\begin{array}{l}\text { No Heat } \\
\text { Treatment }\end{array}$ & & No H2: 2.6 \\
\hline M2 Steel & $\begin{array}{l}\text { Metal Samples } \\
\text { Co., AL, USA } \\
\end{array}$ & $\begin{array}{l}4 \% \mathrm{Cr} 2 \% \mathrm{~V} \\
5 \% \mathrm{Mo} 6 \% \mathrm{~W}\end{array}$ & Yes & \begin{tabular}{|l} 
No Heat \\
Treatment \\
\end{tabular} & & No H2: 3.1 \\
\hline $\begin{array}{l}\text { AISI H13 } \\
\text { Flat }\end{array}$ & $\begin{array}{l}\text { Christopher Tool, } \\
\text { Ohio, USA }\end{array}$ & $\begin{array}{l}\text { AISI H13 }(5 \% \mathrm{Cr} \\
1.3 \% \mathrm{Mo} 1.1 \% \mathrm{~V})\end{array}$ & $\begin{array}{l}\text { No - from } \\
\text { Manufacturer }\end{array}$ & $\begin{array}{l}\text { Through } \\
\text { hardened Rc } \\
65-70\end{array}$ & & $\begin{array}{l}\text { No H2: } 11.0 \\
\text { 100 Hr: } 11.3 \\
1000 \text { Hr: } 10.9\end{array}$ \\
\hline $\begin{array}{l}\text { AISI M2 } \\
\text { Pin }\end{array}$ & $\begin{array}{l}\text { Christopher Tool, } \\
\text { Ohio, USA }\end{array}$ & $\begin{array}{l}\text { AISI M2 }(4 \% \mathrm{Cr} \\
2 \% \mathrm{~V} 5 \% \mathrm{Mo} \\
6 \% \mathrm{~W}) \\
\end{array}$ & $\begin{array}{l}\text { No - from } \\
\text { Manufacturer }\end{array}$ & \begin{tabular}{|l} 
Through \\
hardened Rc \\
$60-65$
\end{tabular} & $\begin{array}{l}\text { WCC Rc } \\
66-72\end{array}$ & \\
\hline Pin 1.592 Flat & $\begin{array}{l}\text { DUAP } \\
\text { Switzerland }\end{array}$ & $\begin{array}{l}\text { DIN } 1.5920 \\
(18 \% C r \text { Ni\%8) }\end{array}$ & $\begin{array}{l}\text { No }- \text { from } \\
\text { Manufacturer }\end{array}$ & $\begin{array}{l}\text { Hardened Rc } \\
60-64\end{array}$ & & $\begin{array}{l}\text { No H2: } 7.26 \\
1000 \text { Hr: } 7.72\end{array}$ \\
\hline Pin 1.3343 Pin & \begin{tabular}{|l} 
DUAP \\
Switzerland \\
\end{tabular} & $\begin{array}{l}\text { DIN } 1.3343 \\
(5 \% \mathrm{Mo} 6 \% \mathrm{~W}) \\
\end{array}$ & $\begin{array}{l}\text { No }- \text { from } \\
\text { Manufacturer }\end{array}$ & $\begin{array}{l}\text { Hardened Rc } \\
60-64\end{array}$ & & \\
\hline $\begin{array}{l}\text { Din } 1.3343 \\
\text { Pin/DLC }\end{array}$ & $\begin{array}{l}\text { DUAP } \\
\text { Switzerland }\end{array}$ & $\begin{array}{l}\text { DIN } 1.3343 \\
(5 \% \mathrm{Mo} 6 \% \mathrm{~W})\end{array}$ & $\begin{array}{l}\text { No }- \text { from } \\
\text { Manufacturer }\end{array}$ & $\begin{array}{l}\text { Hardened Rc } \\
60-64\end{array}$ & \begin{tabular}{|l} 
Ion Bonded \\
a-DLC-HP
\end{tabular} & \\
\hline
\end{tabular}

Table 1: Description of the materials tested, and specifics of each material.

\begin{tabular}{|c|c|c|c|c|c|}
\hline Pin & Flat & Exposure to $\mathrm{H} 2$ & Test environment & $\begin{array}{c}\text { Contact } \\
\text { Stress }\end{array}$ & Test length \\
\hline \multirow{3}{*}{$\begin{array}{l}\text { AISI M2 } \\
\text { (Rc 60-65) }\end{array}$} & \multirow{3}{*}{$\begin{array}{l}\text { AISI H13 } \\
\text { (Rc 65-70) }\end{array}$} & none & Argon, Air & Low $^{1}$, High $^{2}$ & $\mathrm{~S}^{3}, \mathrm{~L}^{4}$ \\
\hline & & $100 \mathrm{hr}$ & Argon & $\mathrm{High}^{2}$ & $\mathrm{~L}^{4}$ \\
\hline & & $1000 \mathrm{hr}$ & Argon, Air & Low $^{1}, \operatorname{High}^{2}$ & $\mathrm{~S}^{3}, \mathrm{~L}^{4}$ \\
\hline \multirow{2}{*}{ Din 1.3343} & \multirow{2}{*}{ Din 1.592} & none & Argon, Air & Low $^{1}$, High $^{2}$ & $\mathrm{~S}^{3}$ \\
\hline & & $1000 \mathrm{hr}$ & Argon, Air & Low $^{1}$, High $^{2}$ & $\mathrm{~S}^{3}$ \\
\hline \multirow{2}{*}{$\begin{array}{l}\text { Din } 1.3343 \\
\text { DLC coating }\end{array}$} & \multirow{2}{*}{$\begin{array}{l}\text { AISI H13 } \\
\text { (Rc 65-70) }\end{array}$} & none & Argon & $\mathrm{High}^{2}$ & $\mathrm{~L}^{4}$ \\
\hline & & $\begin{array}{l}100 / 1000 \mathrm{hr} \\
\text { Ave.: } 550 \mathrm{hr}\end{array}$ & Argon & $\operatorname{High}^{2}$ & $\mathrm{~L}^{4}$ \\
\hline \multirow{2}{*}{$\begin{array}{l}\text { Din } 1.3343 \\
\text { DLC coating }\end{array}$} & \multirow[b]{2}{*}{ Din 1.592} & none & Argon & $\operatorname{High}^{2}$ & $\mathrm{~L}^{4}$ \\
\hline & & $\begin{array}{l}100 / 1000 \mathrm{hr} \\
\text { Ave.: } 550 \mathrm{hr}\end{array}$ & Argon & $\operatorname{High}^{2}$ & $\mathrm{~L}^{4}$ \\
\hline $\begin{array}{l}\text { M2 steel } \\
\text { (Untreated) }\end{array}$ & $\begin{array}{c}\text { H13 steel } \\
\text { (Untreated) }\end{array}$ & $1000 \mathrm{hr}$ & Argon & $\operatorname{High}^{2}$ & $S^{3}$ \\
\hline
\end{tabular}

\footnotetext{
${ }^{1}$ Pin tip radius $12.7 \mathrm{~mm}($ Contact Stress $=93.2 \mathrm{MPa})$

${ }^{2}$ Pin tip radius $3.175 \mathrm{~mm}($ Contact Stress $=530.9 \mathrm{MPa})$

${ }^{3}$ Short test 6250 cycles

${ }^{4}$ Long test $67150-108000$ cycles
}

Table 2: Matrix of the test materials and conditions of the test. 


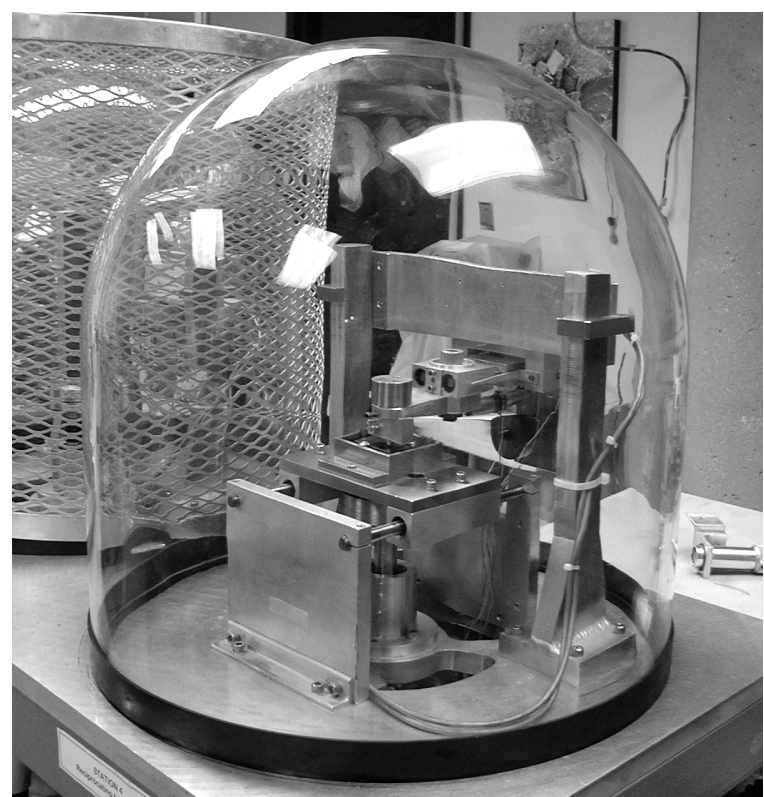

Figure 8: Reciprocating sliding test setup in Argon environment.

Short sliding tests, 6250 cycles, were used to screen materials, and determine the effects of environment and contact stress (pin tip radius). Some observations have been made:

- The scuffing-resistance is very significantly different for different materials. Self-mated DUAP and M2/H13 failed (scuffing indicated by a fast friction transition) in very short periods (150-250 cycles), however the self-mated CT survived the full 6250-cycle test, as shown in Fig. 2. It was noticed that the M2 and H13 steels had unexpectedly low hardness, 3.1 and 2.6 GPa (HV), respectively, probably due to improper heattreatments. Thus, no further tests were conducted for M2 and H13 steels.

- It was quickly found out that oxidative wear dominated the wear mechanism for the tests conducted in air as indicated by brown color wear debris (see Fig. 3), and cause scuffing occur earlier as shown in Fig. 4. Therefore, an inert environment (argon) is more appropriate and used thereafter for testing these needle-nozzle materials because of no oxygen in hydrogen-fuel engines.

- Tests using different pin tip radii produced similar friction behavior except the smaller tip radius produced a quicker friction transition - onset of scuffing, as shown in Fig. 5. Self-mated CT did not scuff in the short tests, and long tests were needed. In order to accelerate scuffing failure, tips with radii of $3.175 \mathrm{~mm}$ were used in the long tests.

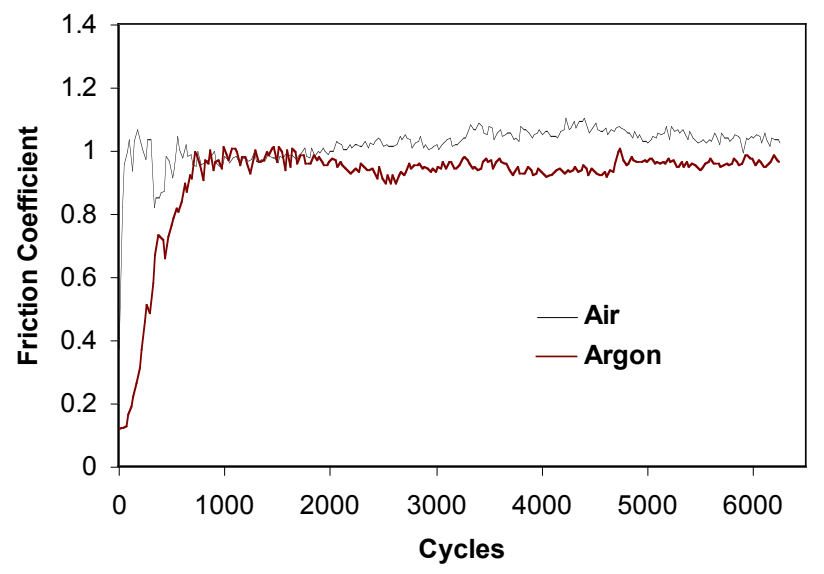

Figure 9: Effects of environment (DUAP pin /DUAP flat, $1000 \mathrm{~h} \mathrm{H}_{2}$ exposure)

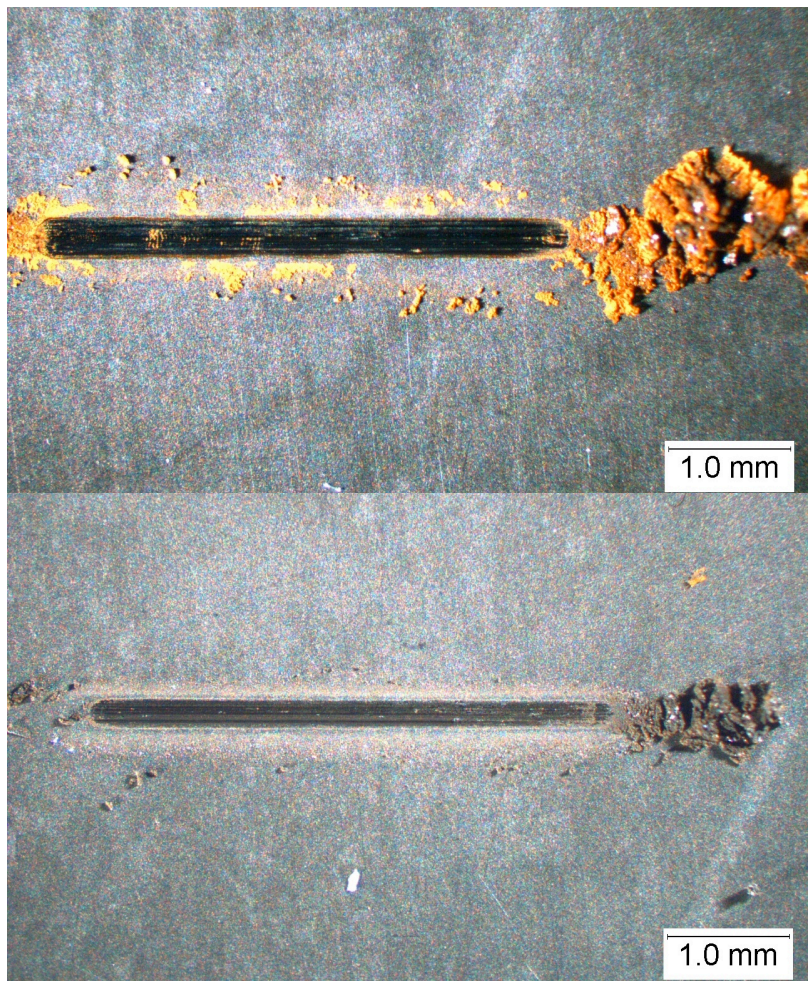

Figure 10: Wear scars on DUAP flats produced in air (left) and argon (right). 


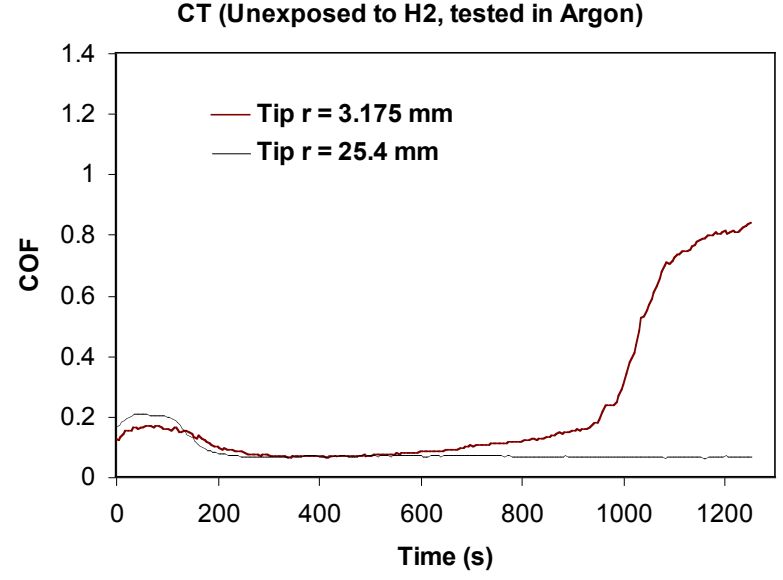

Figure 11: H13 (Rc 65-70) flat /M2 (Rc 60-65) pin: Unexposed to H2, Tested in $\mathrm{Ar}$

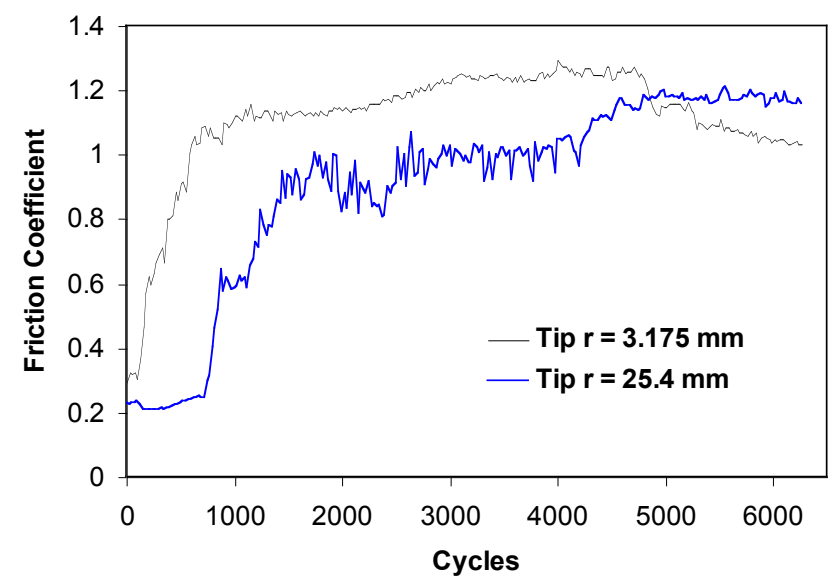

Figure 12: Din 1.592 Flat/1.3343 Pin: Unexposed to $\mathrm{H} 2$, tested in argon)

CT (Tested in Air, Tip r $=3.175 \mathrm{~mm}$ )

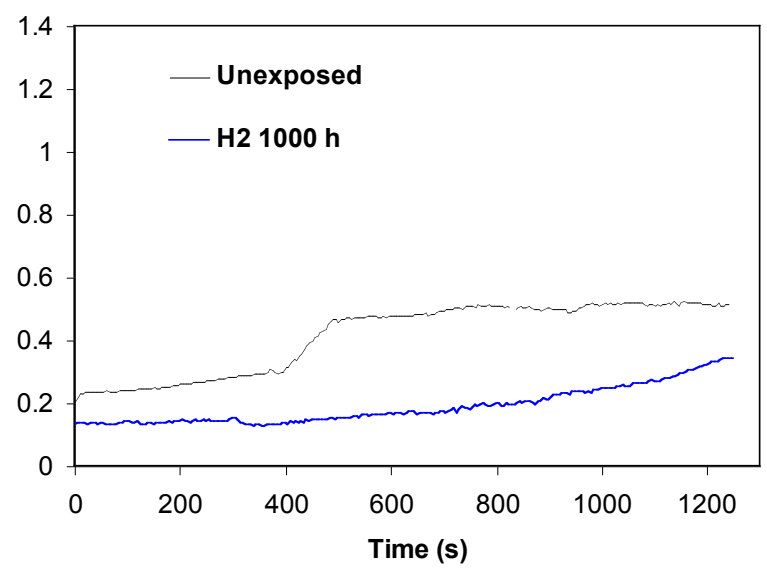

Figure 13: Effect of hydrogen exposure - H13 (Rc 65-70) /M2 (Rc 60-65) matched pair, tested in air.

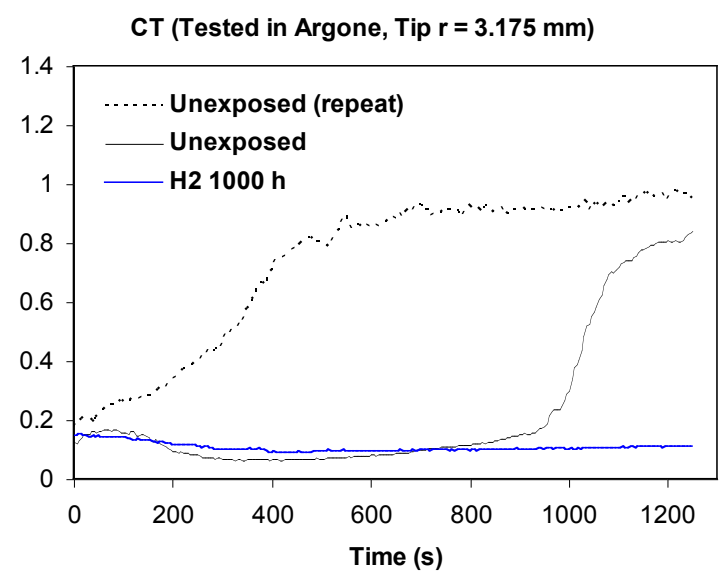

Figure 14: Effect of hydrogen exposure - H13 (Rc 65-70) /M2 (Rc 60-65) matched pair, tested in argon.

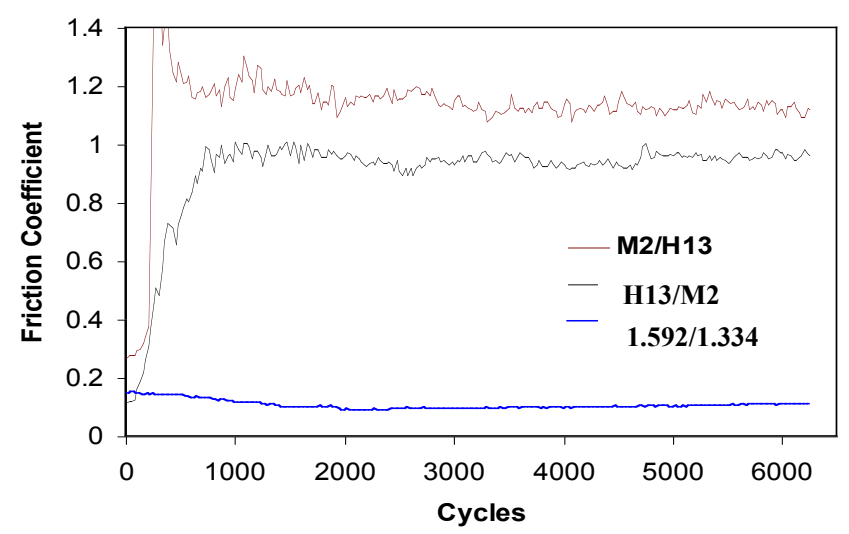

Figure 15: H13 (Rc 65-70) flat /M2 (Rc 60-65) pin showed much higher scuffing-resistance $(6250 \mathrm{Cy}-$ cles) than Din 1.592 Flat/1.3343 Pin and M2/H13 (No heat treatment, 150-250 Cycles).

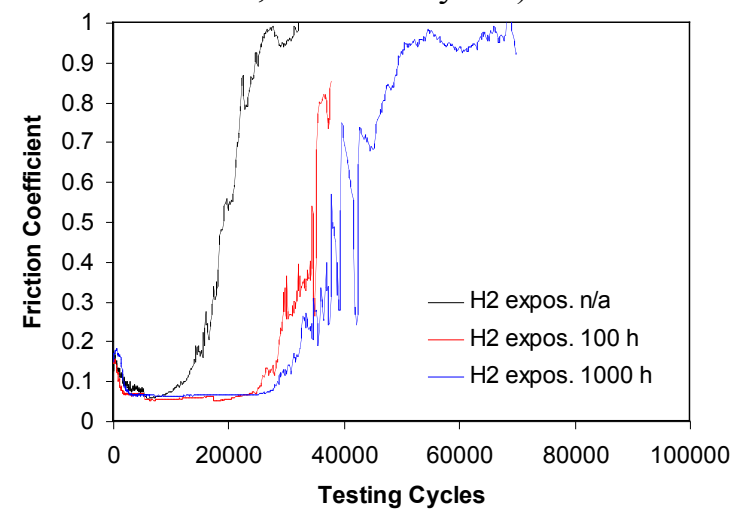

Figure 16: Friction traces for $\mathrm{H} 13$ (Rc 65-70) flat /M2 (Rc 60-65) pin: H2 exposure results in lower scuffing resistance. 


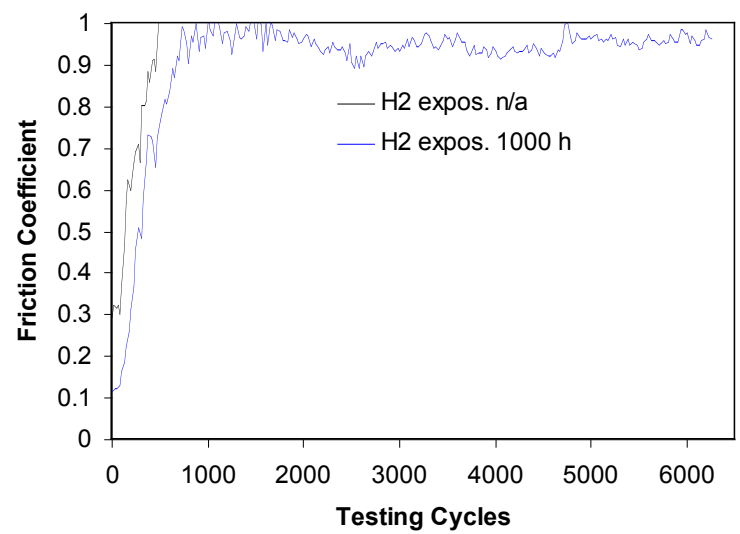

Figure 16: Friction traces for Din 1.592 Flat/1.3343 Pin. (Note: the X-axis scale is one order of magnitude lower than other materials)

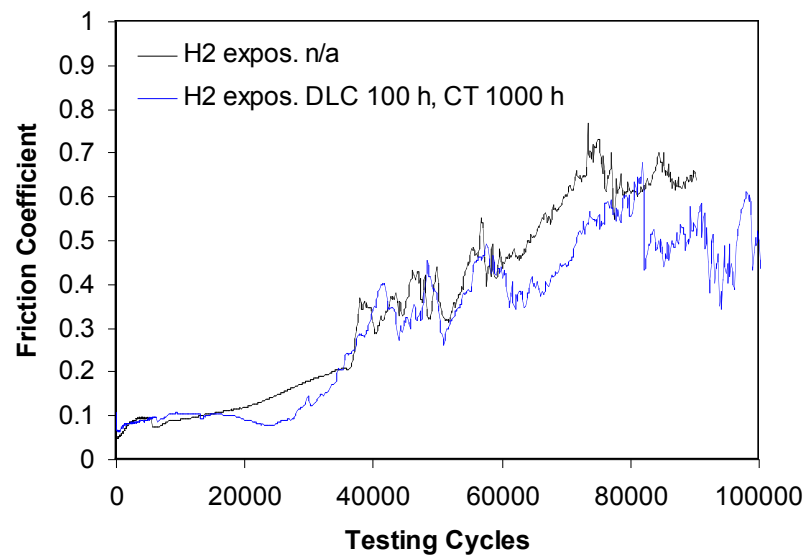

Figure 17: Friction traces for DLC-coated 1.3343 pin/ H13 (Rc 65-70) flat. H2 exposure results in lower scuffing resistance.

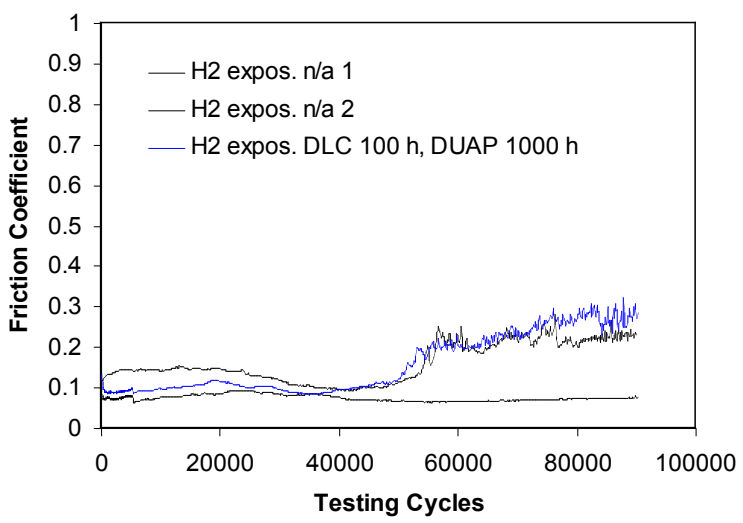

Figure 18 Friction traces for DLC-coated Din 1.3343 pin/Din 1.5920 flat.

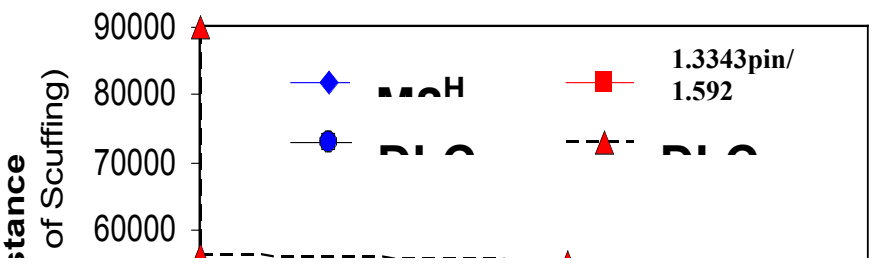

Figure 19: Summary of scuffing-resistance of four material combinations with various hydrogen exposure lengths.

Observations are summarized below.

1. Material hardness is the biggest factor in low $\mathrm{H} 2$ exposure.

- M2 pin/H13 flat heat-treated material showed more than 100x higher scuffing-resistance.

- M2 pin/H13 flat heat-treated material wear was minimum and not measurable by profilometer.

2. Environment did play an important role.

- Lower friction coefficient achieved in argon than in air for H-exposed samples.

- Different wear modes were observed: oxidizedwear dominating in air and abrasive-wear dominating in argon.

- Wear volumes produced in argon were significantly less (by 40-80\%) than those in air.

3. Static (initial) friction lowest in M2 pin/H13 flat heat-treated material pair, decreases with $\mathrm{H} 2$ exposure $(\sim 0.05)$.

4. Hydrogen exposure does have effects on frictional behavior.

- Longer Hydrogen exposure leads to higher scuffing-resistance.

5. Replacing Din 1.3343 pin with a DLC-coated Din 1.3343 pin against the Din 1.592 flat improved scuffing-resistance by $200 x-600 x$

- Perhaps due to transfer film development.

6. Hydrogen exposure for DLC-coated pins did not influence scuffing-resistance. 
7. DLC-coated din 1.3343 pin/Din 1.592 flat $e x-$ hibited the highest scuffing-resistance and lowest friction coefficient after scuffing among the test material pairs in both hydrogen exposed and nonexposed conditions.

\section{In-Situ Friction-Wear of Needle-Nozzle Materials}

The in-situ friction-wear test apparatus has been employed to study the characteristics of representative materials. Wear testing began in pure hydrogen using hardened H13 tool steel wear blocks and a hardened M2 steel pin in a linear sliding pin-onblock mode. The pin radius of 0.25 " and normal force of $118.2 \mathrm{~g}$ give a normal contact stress of 415 MPa for the initial tests. Ten thousand wear cycles were made in air and in pure hydrogen at $1000 \mathrm{psi}$ and 1500 psi at ambient temperature. Each wear cycle is 0.4 " in length and during a cycle the pin slides 0.2 " in each direction (forward and reverse). Each wear cycle is $1.016 \times 10^{-2} \mathrm{~m}$ or approximately $10-\mathrm{mm}$ in length so that $10^{4}$ wear cycles is $101.6 \mathrm{~m}$ and this requires 7.5 hours of testing. The small wear fixture (Figure 20) fits into the PNNL highpressure autoclaves and the transverse force during each wear cycle is recorded in each direction over the portion of the wear track that is constant velocity and that is away from the ends of the wear tracks where the sliding reverses direction.

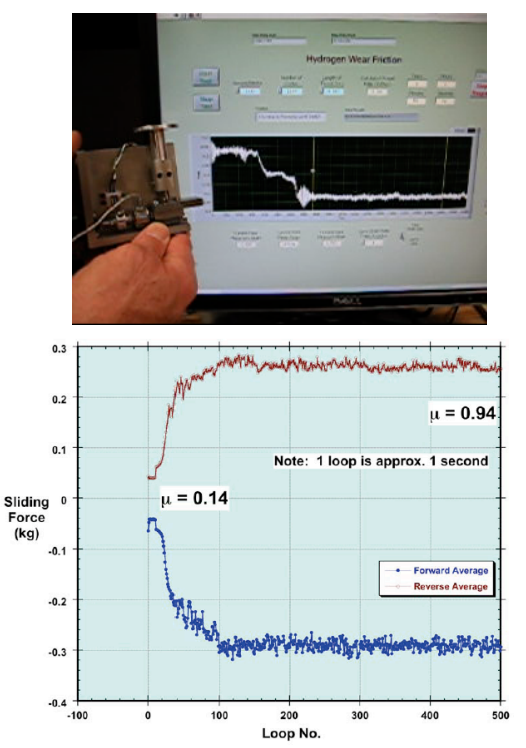

Figure 20: In-situe friction and wear reciprocating test apparatus (top) with close up of the software output.
Three tests were performed on the initial test block of hardened H13 tool steel, which had a Vickers hardness of 639 (57 Rc). The M2 pin was not hardness tested but should be of similar harness value. The first test was in laboratory air and the remaining two tests were performed in the sealed and pressurized autoclave at $1000 \mathrm{psi}$ and 1500 psi hydrogen, respectively. The wear data consist of the wear rate, the friction stress, and micro-structural observations of the wear track and debris. Figure 21 shows the friction force as a function of sliding distance for the three conditions.

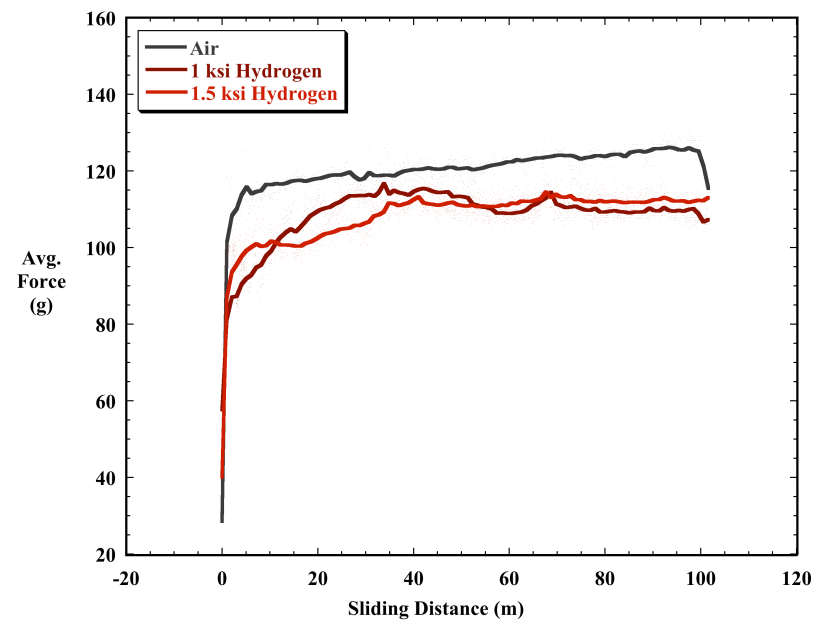

Figure 21: Wear data in terms of sliding friction force as a function of sliding distance on $\mathrm{H} 13$ block with an M2 pin in the indicated environment. Tests were performed at ambient temperature and the pin was resurfaced between wear tests. The applied normal force was 118.2 grams.

The data was reduced by normalizing by the applied normal force to give the sliding coefficient of fraction for these materials and environments. Friction coefficients were near unity in hydrogen and slightly above unity in air. This is shown in Figure 22. 


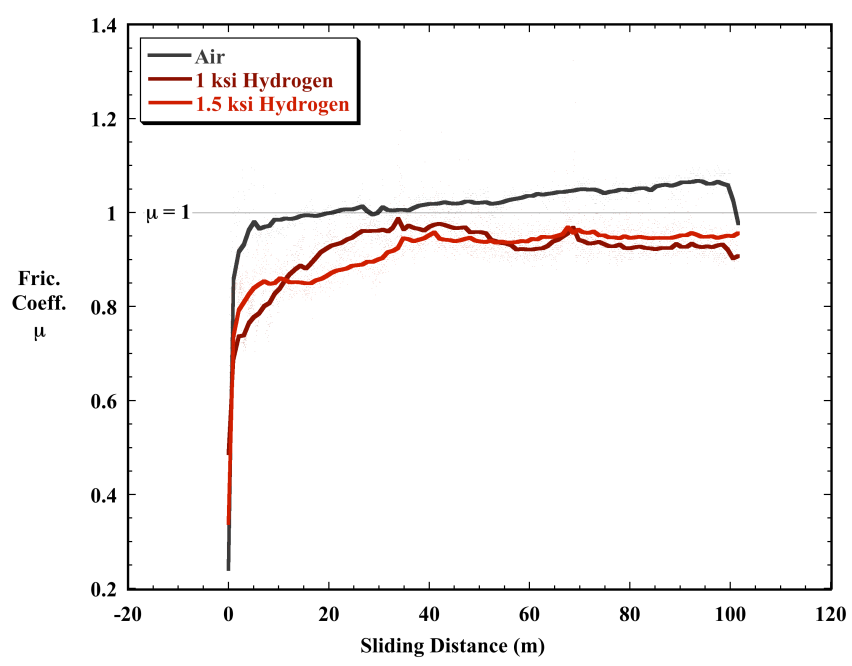

Figure 22: Sliding friction coefficient as a function of sliding distance in the indicated environment. The friction coefficient is slightly lower in pure hydrogen compared to air.

A Veeco DEKTAK Profilometer with a stylus width of $12.5 \mu \mathrm{m}$ was used to determine the wear track dimensions. These data are presented in Figure 23 (a-c) for the runs in air and two pressures of hydrogen. The wear track profiles are wider in hydrogen as compared to air and more material has been removed in hydrogen. More tests will be needed to confirm this trend, however. The associated profile data are listed in Table 3 and the wear track profiles fit to a parabola are shown in Figure 24.

\begin{tabular}{|l|l|l|l|}
\hline Sample & $\begin{array}{l}\text { Depth } \\
(\mu \mathrm{m})\end{array}$ & $\begin{array}{l}\text { Width } \\
(\mu \mathrm{m})\end{array}$ & $\begin{array}{l}\text { Area of Mat- } \\
\text { ter Removed } \\
\left(\mu \mathrm{m}^{2}\right)\end{array}$ \\
\hline Air & $12.6 \mu \mathrm{m}$ & 454.5 & 2863.4 \\
\hline $1 \mathrm{ksi} \mathrm{H} 2$ & 13.6 & 488.7 & 3323.2 \\
\hline $1.5 \mathrm{ksi} \mathrm{H} 2$ & 12.0 & 613.7 & 3682.2 \\
\hline
\end{tabular}

Table 3: Profilometry data from the in-situ tested needle-nozzle materials.

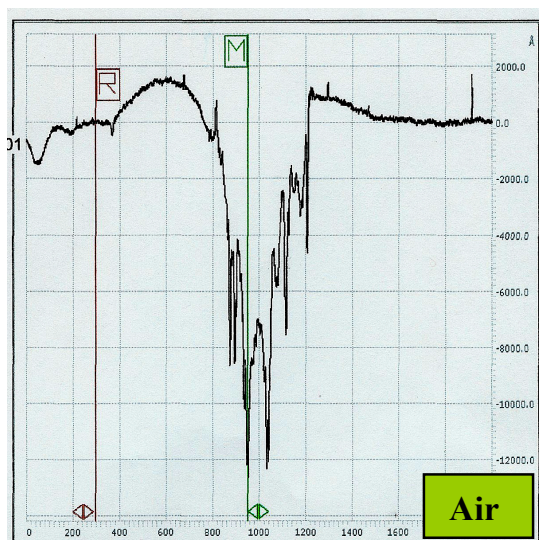

(a)

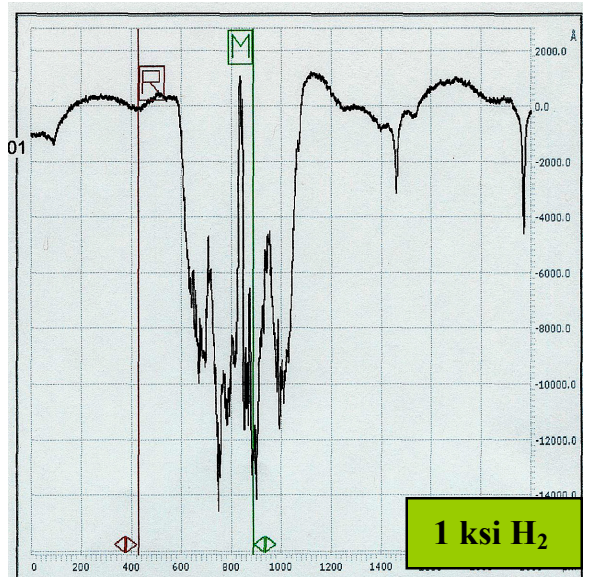

(b)

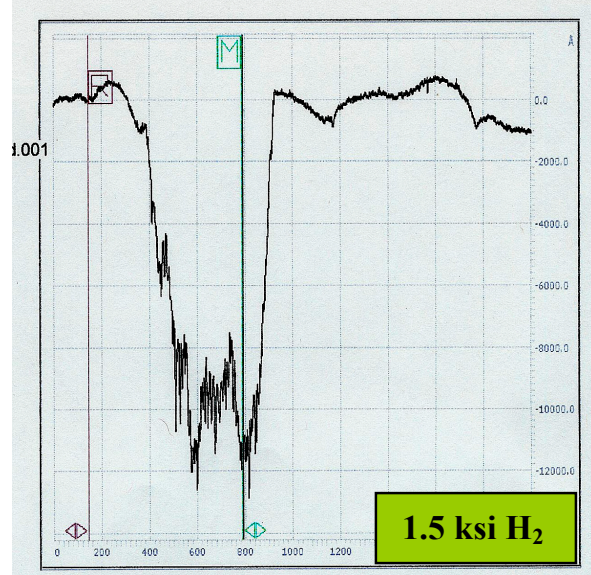

(c)

Figure 23: Profilometry data for the three wear tracks in a) laboratory air, b) $1 \mathrm{ksi}_{2}$, and c) $1.5 \mathrm{ksi}$ $\mathrm{H}_{2}$. The wear tracks in hydrogen are wider than the track in air. 


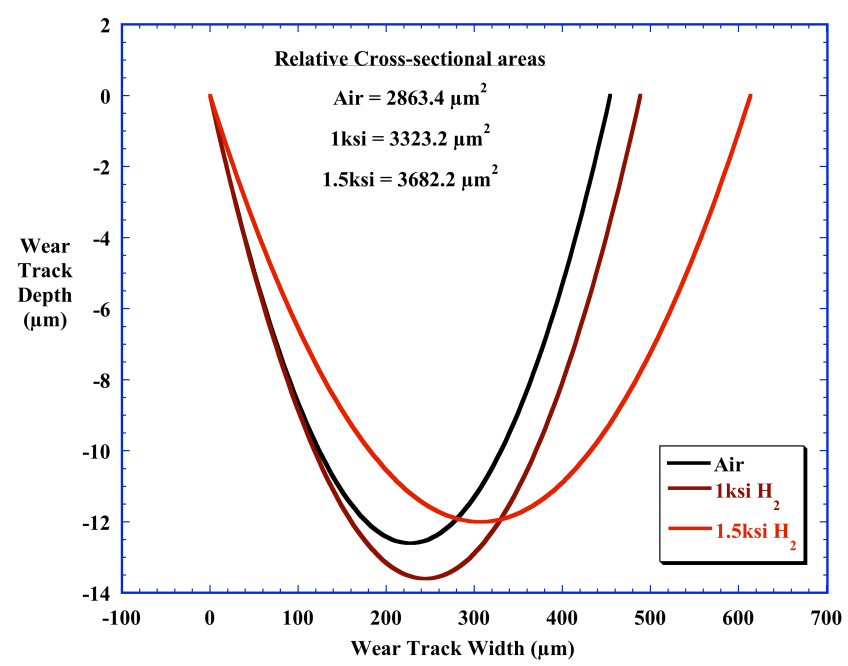

Figure 24: Wear track profiles fit to an assumed parabolic shape showing the width increasing as a function of hydrogen pressure and area of material removed also increasing with increasing hydrogen pressure.

From Figure 24, it is apparent that the effect of hydrogen in the in-situ apparatus reduces the wear track depth. Wear track images are shown in Figure 25 which represent $\mathrm{H} 13$ hardened steel flats $(57 \mathrm{Rc}$ hardness) with D08 hardened pins. The actual tracks are depicted in Figure 26 a-c. It appears that the mechanism is different in the hydrogen tests than that in air; this reflects the different wear depth and corresponding volume. A thorough test plan will explore this further in FY08.

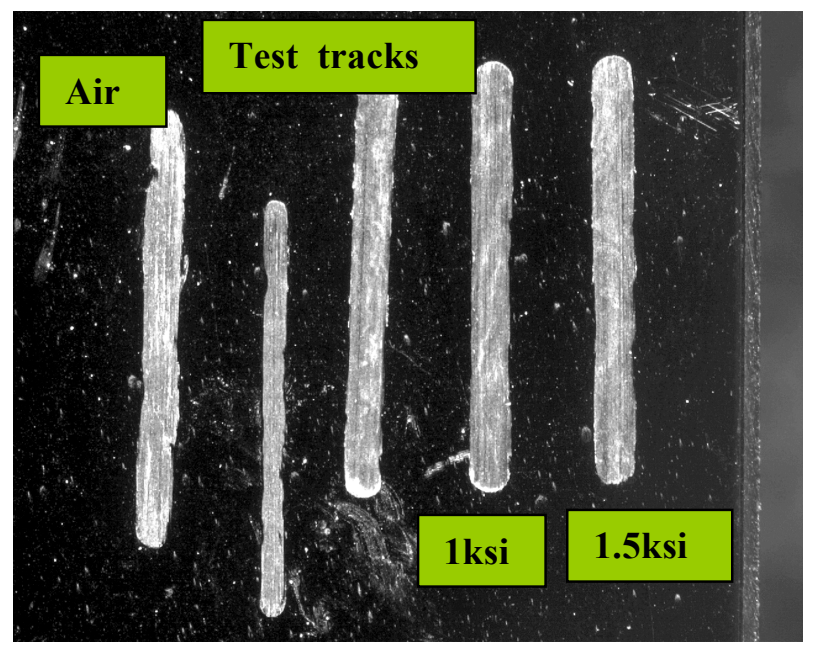

Figure 25: Optical micrograph of $\mathrm{H} 13$ wear block surface with oblique lighting showing wear tracks as labeled.

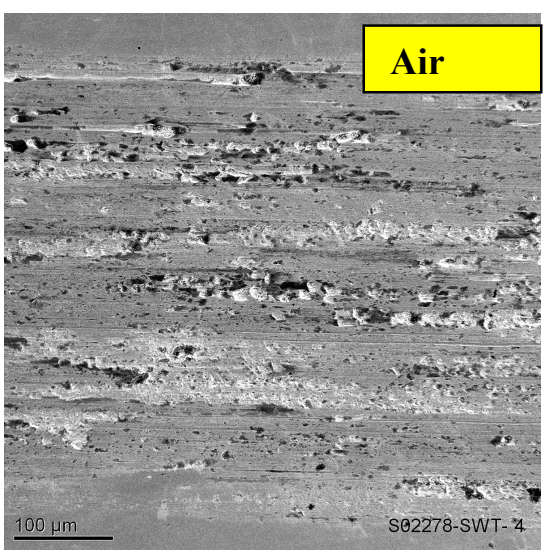

(a)

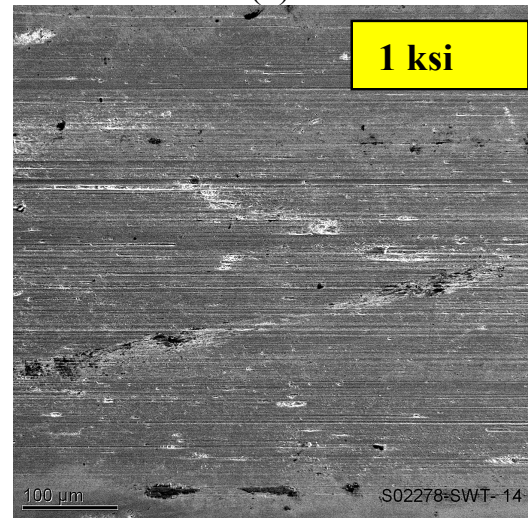

(b)

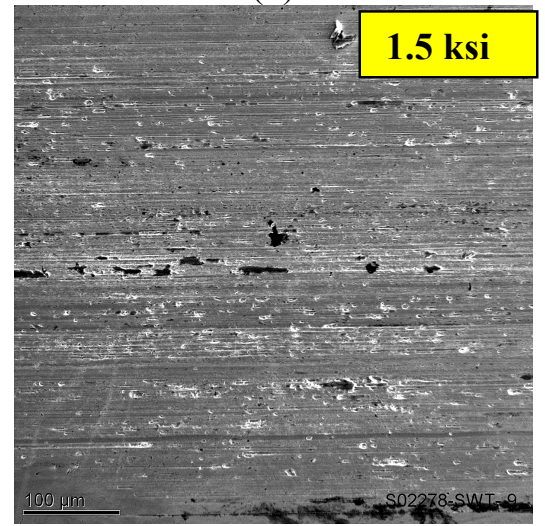

(c)

Figure 26: SEM micrographs of wear tracks after 10000 cycles or $100 \mathrm{~m}$ of wear of H13 steel with M2 steel pin in a) air, b) $1 \mathrm{ksi} \mathrm{H}_{2}$, and c) $1.5 \mathrm{ksi} \mathrm{H}_{2}$. The wear track in air has noticeably more oxide particle debris and evidences a higher friction value.

\section{Piezoelectric Actuator Test-Analysis}

The performance of piezoelectric actuators has been evaluated in a high-pressure hydrogen autoclave. 
The autoclave chamber has a pressure rating of 60 $\mathrm{MPa}$ and a temperature limit of about $400^{\circ} \mathrm{C}$. The system to electrically energize the actuators consists of a power supply controlled by a computer data acquisition system running LabView software. The system is pressurized from high-pressure gas bottles and the oxygen content is determined using an oxygen analyzer.

In previous research, extensive failure analysis was conducted on failed piezo actuators. In order to further understand the mechanism for failure, in-situ imaging of the piezo actuator has been conducted to verify failures under hydrogen service. The in-situ experiments, combined with extensive failure analysis, has prompted a study of the polymer piezo coating material.

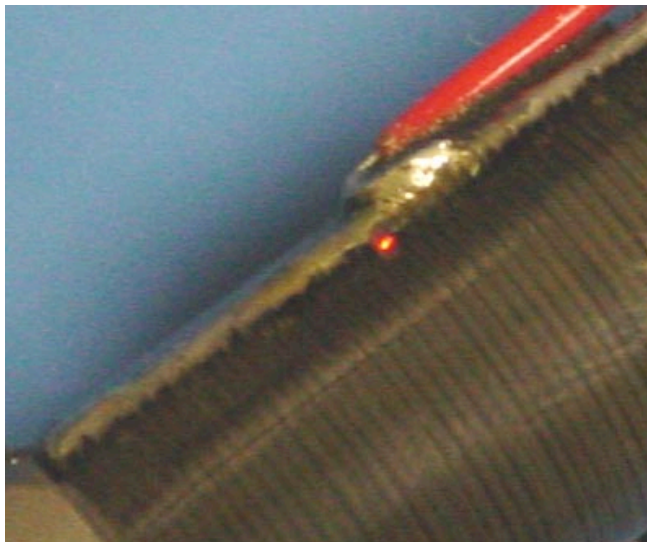

Figure 27: Failure point glowing with $40 \mathrm{~mA}$ average input current.

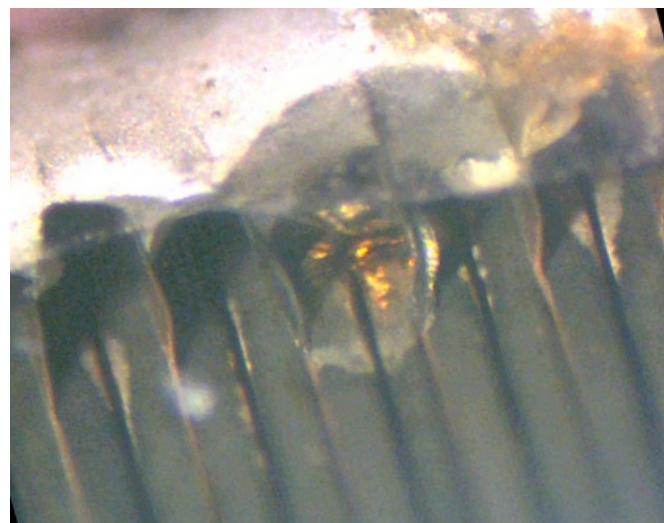

Figure 28: Zone near arc site (two positive and one negative electrode). Delamination edge starting at negative electrodes is shown.

\section{Piezo Epoxy Coating - Testing}

From previous tests, it was determined that the electrode interface were one source of failure on the actuators. The epoxy coating, as shown in failure analysis images presented in last years report, and in Figure 29, may either delaminate from the piezo or blister, either case detrimental to performance. PNNL tested both epoxy coatings provided by the supplier and through experimentation, identified that the glass transition was dramatically lower than anticipated, and that neither was fully cured. Table 4 (a) indicates epoxy $\mathrm{Tg}$ between $45-51{ }^{\circ} \mathrm{C}$ for Epoxy A (tested via Differential Scanning Calorimeter [DSC] and Dynamic Mechanical Analysis [DMA]) and between $22-32^{\circ} \mathrm{C}$ for Epoxy B, both too low for $100^{\circ} \mathrm{C}$ service temperatures.

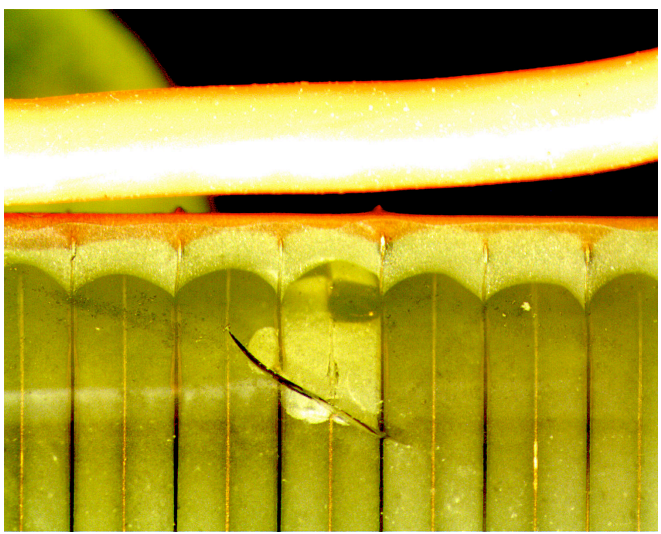

Figure 29: Delamination of the epoxy coating from the piezo stack under temperature and hydrogen exposure.

\begin{tabular}{|c|c|c|c|c|}
\hline \multirow{2}{*}{ Epoxy } & \multicolumn{3}{|c|}{$\mathbf{T}_{\mathbf{g}}\left({ }^{\mathbf{0}} \mathbf{C}\right)$} \\
\cline { 2 - 5 } & \multicolumn{2}{|c|}{ DSC } & \multicolumn{2}{c|}{ DMA } \\
\cline { 2 - 5 } & $\begin{array}{c}\text { As Re- } \\
\text { ceived }\end{array}$ & $\begin{array}{c}\text { Fully- } \\
\text { Cross } \\
\text { linked } *\end{array}$ & $\begin{array}{c}\text { As Re- } \\
\text { ceived }\end{array}$ & $\begin{array}{c}\text { Fully- } \\
\text { Cross } \\
\text { linked * }\end{array}$ \\
\hline A & 45.16 & increase & 50.8 & - \\
\hline \multirow{2}{*}{ B } & 22.3 & $\begin{array}{c}\text { slight } \\
\text { increase }\end{array}$ & 31.87 & - \\
\hline
\end{tabular}

\begin{tabular}{|c|c|c|}
\hline \multirow{2}{*}{ Epoxy } & \multicolumn{2}{|c|}{ Delta H (J/g) } \\
\cline { 2 - 3 } & As Received & Fully-Cross linked * \\
\hline A & -1.322 & - \\
\hline B & -5.056 & - \\
\hline
\end{tabular}

* Fully cross linked is the second run on the same sample

Table 4: Epoxy Tg via DSC and DMA, and residual heat (bottom table) in each epoxy indicating significant uncured portion of the polymer. 
The DMA plot illustrated in Figure 30 clearly indicates the Tg differences between epoxies $\mathrm{A}$ and $\mathrm{B}$; peaks indicate a $\mathrm{Tg}$ of $31.87^{\circ} \mathrm{C}$ for $\mathrm{B}$ and a transition indicating a $\mathrm{Tg}=50.80^{\circ} \mathrm{C}$ for $\mathrm{A}$.

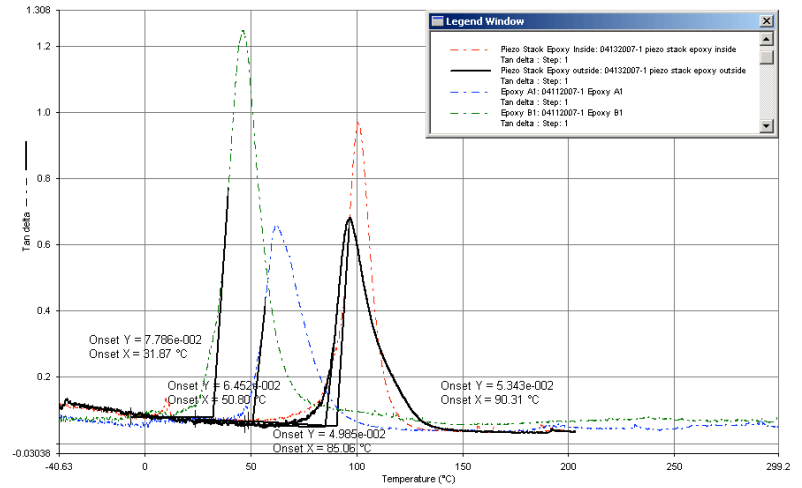

Figure 30: DMA output of the Tg for Epoxy A and B.

The DSC plots provide a second indication of the $\mathrm{Tg}$ for each polymer $\mathrm{A}$ and $\mathrm{B}$, and the residual heat in each that represents un-crosslinked polymer. This clearly indicates that each polymer was not fully cured; this can be seen in Figure 31. The discoloration of each epoxy coating in Figure 32 indicates that a post-cure of $200^{\circ} \mathrm{C}$ causes significant polymer degration.

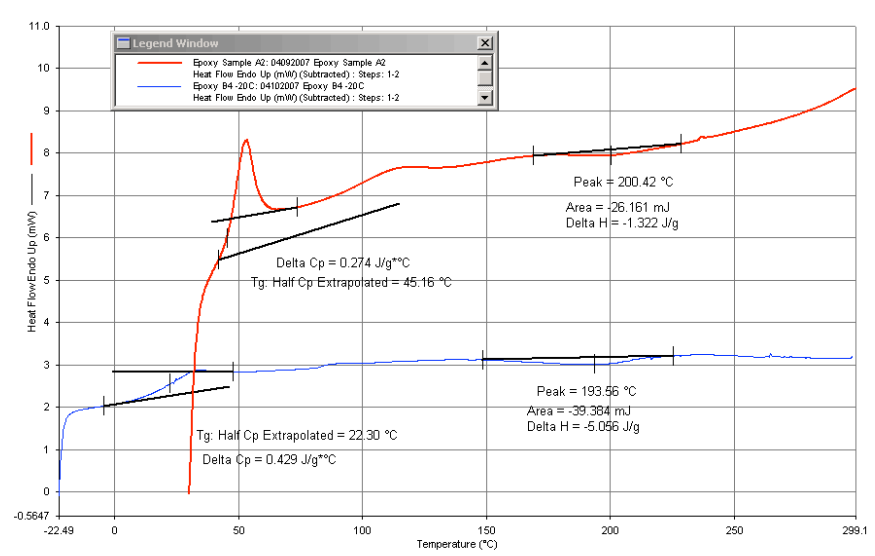

Figure 31: DSC output of the $\mathrm{Tg}$ and $\Delta \mathrm{H}$ of Epoxy $\mathrm{A}$ and $\mathrm{B}$. Note that the $\Delta \mathrm{H}$ of Epoxy $\mathrm{B}$ is approximately $5 \mathrm{x}$ that of Epoxy A; neither is fully cured nor are they appropriate for service temperatures near the $200^{\circ} \mathrm{C}$ design temperature.

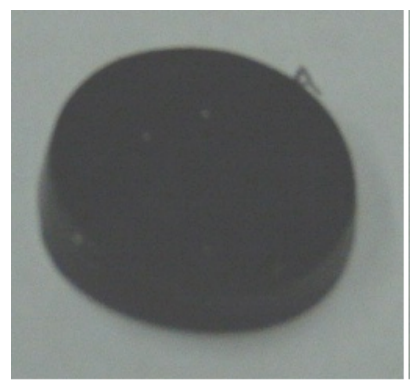

Post Cure

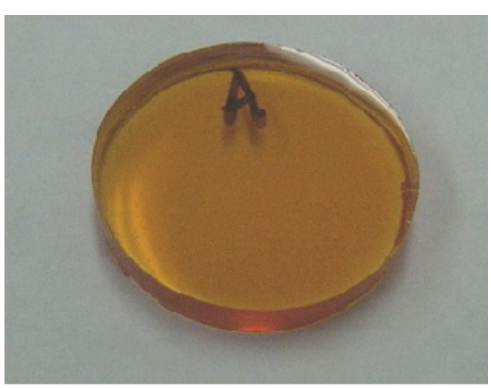

As Received
As Received and post cure photographs of Epoxy B

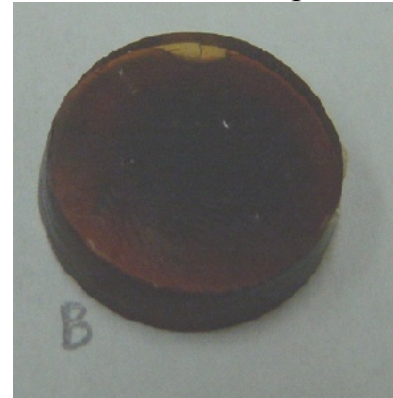

Post Cure

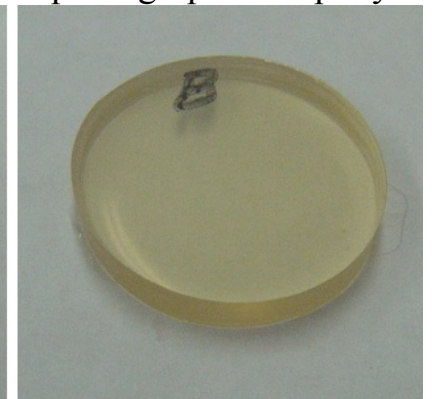

As Received
Figure 32: Images of Epoxy A and B disks in the "As-Received" and post cure conditions. The effect of polymer degradation due to $200^{\circ} \mathrm{C}$ exposure is shown.

From these tests, we have determined that the design currently under consideration must utilize a different polymer system, or the piezo stack needs to be further isolated from temperatures above $50^{\circ} \mathrm{C}$ and any prolonged hydrogen exposure. This would require a re-design or novel polymer coatings; PNNL is working with several suppliers to identify polymer coatings that may qualify for this application. 


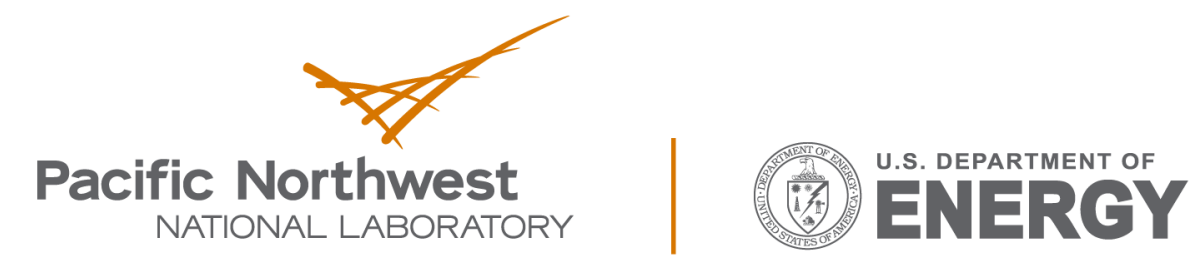

Proudly Operated by Battelle Since 1965

902 Battelle Boulevard

P.O. Box 999

Richland, WA 99352

1-888-375-PNNL (7665)

www.pnnl.gov 